\title{
IMPROVEMENT OF LATERAL CONNECTIVITY IN A SECTOR OF RIVER HÂRTIBACIU (OLT/DANUBE BASIN)
}

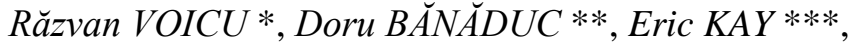 \\ Erika SCHNEIDER-BINDER **** and Angela CURTEAN-B $\breve{A N} \breve{D U C}$ **
}

* National Institute of Hydrology and Water Management, București-Ploiești Street 97, București, Romania, RO-013686, rzvnvoicu@yahoo.com, getiiliberi@gmail.com

** "Lucian Blaga" University of Sibiu, Applied Ecology Research Center, Dr. Ion Raţiu Street 5-7, Sibiu, Sibiu County, Romania, RO-550012, angela.banaduc@ulbsibiu.ro, ad.banaduc@yahoo.com

*** Kay and Associates, Island Highway 8712, Black Creek, B. C., Canada, V9J 1K5, erickay@kayassociates.com

**** Karlsruhe Institute for Technology - University of Land Baden-Württemberg and Research Center of the Helmholtz Society, Institute for Geography and Geoecology, Department WWF-Institute for Floodplain Ecology, Josefstrasse 1, Rastatt, Germany, D-76437, erika.schneider@kit.partner.edu, erika.schb@t-online.de

DOI: 10.1515/trser-2017-0013

KEYWORDS: Alțâna, lotic system, conservation, Rhodeus sericeus, Anodonta cygnea.

\section{ABSTRACT}

The Hârtibaciu River in the Alţâna area has a disturbed lateral connectivity owing to its lateral embankments, as a result of which fish communities in this river sector are negatively influenced. The method of obtaining the water supply for a new proposed wetland is by gravitation, and any excessive water supply to the wetland will be controled and directed to the Hârtibaciu River in a natural manner. A state-of-the-art man-made wetland should increase the quality of the habitat for local fish communities, especially for the Rhodeus sericeus population, which is a species of conservation interest.

ZUSAMMENFASSUNG: Die Verbesserung der lateralen Konnektivität in einem Abschnitt des Harbach-Flusses/Einzugsgebiet Alt/Donau.

Der Hârtibaciu/Harbach hat bedingt durch die Seitendämme in Alțâna/Alzen eine gestörte laterale Konnektivität, wodurch die Fischgemeinschaft in diesem Abschnitt negativ beeinflusst wird. Die Methode für ein neu anzulegendes Feuchtgebiet die Wasserversorgung zu sichern, wird über Gravitation gelöst, wobei der Überschuss an eingeleitetem Wasser kontrolliert und auf natürlichem Weg wieder dem Hârtibaciu/Harbach zugeführt wird. Ein auf dem neusten Stand des Wissens angelegtes Feuchtgebiet soll die Lebensraumqualität für die lokale Fischgemeinschaft verbessern, insbesondere für die Population von Rhodeus sericeus, eine Art von besonderem Naturschutz fachlichem Interesse.

REZUMAT: Îmbunătăţirea conectivității laterale într-un sector al râului Hârtibaciu (Bazinul Olt/Dunăre).

Râul Hârtibaciu în zona Alţâna are o conectivitate laterală deteriorată datorită îndiguirilor fapt care influenţează negativ comunitatea de peşti din acest sector de râu. Metoda de a da sursă de apă unei zone umede nou propuse este realizată prin gravitație, iar surplusul de debit de apă din zona umedă va fi controlat și dirijat spre râul Hârtibaciu într-un mod natural. O zonă umedă nouă, conectată cu râul trebuie să crească calitatea habitatului pentru comunitățile de pești locale, în special pentru poluaţia de Rhodeus sericeus - specie de interes conservativ. 


\section{INTRODUCTION}

The rivers and streams connectivity, and the connectivity between them and their floodplains increases the preservation of areas for the needed specific habitat, tempers a variety of types of elements which affect the dynamics of ecosystems, improves the access to the subteranean water flows, improves the quality of water and soil, expands the depository potential for beneficial sediments, increases the flux of nutrients, depletes flood energy dispersion, rejuvenates floodplain and riparian biocoenoses and provides the ecosystem sustainability. (Gumpinger and Scheder, 2008; Ickes et al., 2005; Van Wilgen et al., 1998; Bănăduc et al., 2016; Hapciuc et al., 2016; Jeeva et al., 2011; Hoancă et al., 2014)

In EU, the Water Framework Directive decided modern guidelines for water, with the purpose of avoiding the deterioration of aquatic and semi-aquatic ecosystems. Only if the natural water course is managed within an integrated continuous manner, an optimum hydromorphological and ecological dynamic can be obtained (Biswas, 2008).

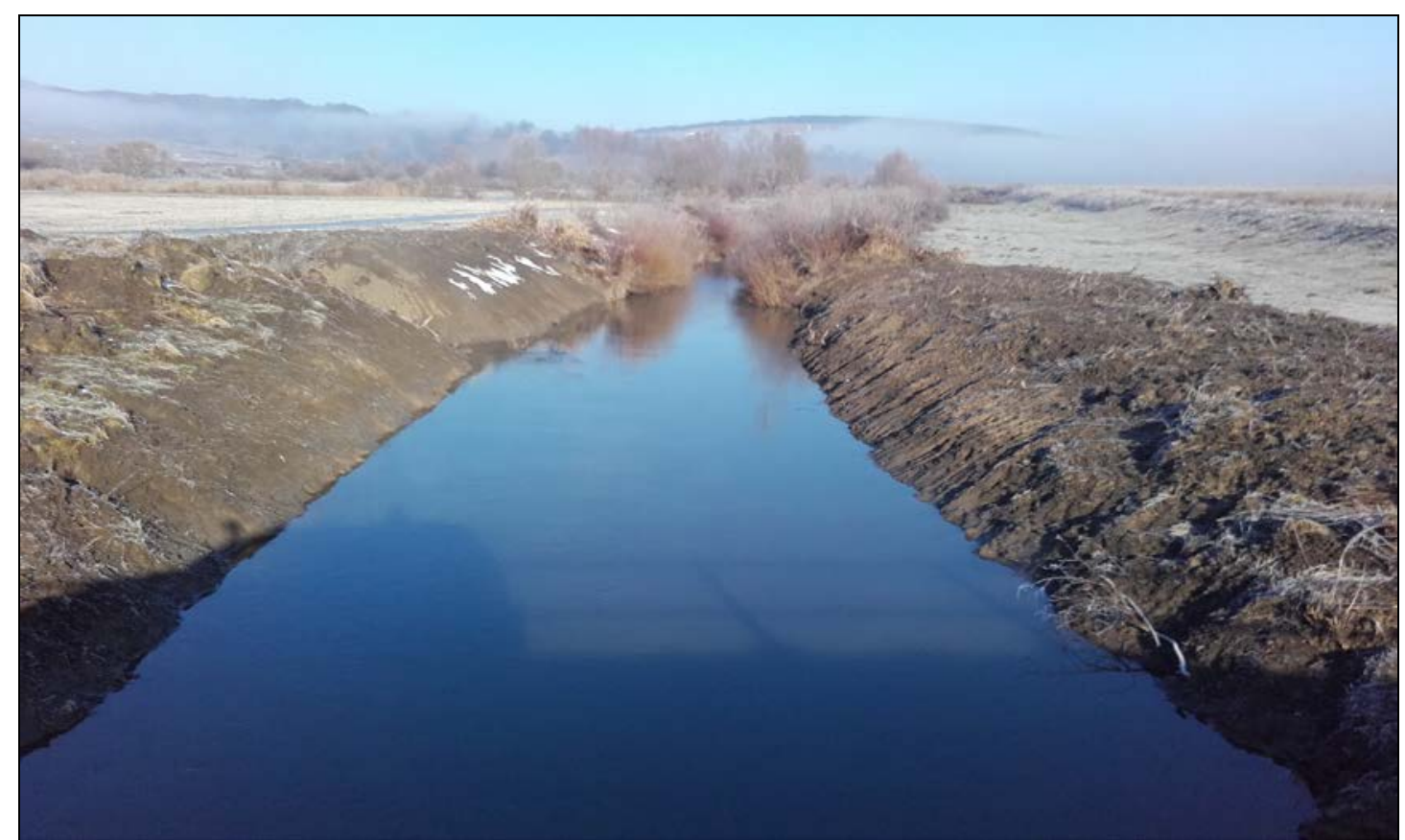

Figure 1a: Human impact on the Hârtibaciu River studied sector on banks and riverbed.

In the researched area, the connectivity between the river and its floodplain was diagnosed as a needed achievable result, to support proper environment circumstances that would meet the objectives of re-establishing lateral connectivity and preventing the related risks, to all-encompassing habitats and biocoenoses, of which the fish populations belong.

For this area which is under anthropic impact it is also necessary to restore the river, the adjacent floodplain and the connectivity between them as much as possible, with the proposed solutions being based on scientific adapted concepts (Voicu and Dominguez, 2016). Disrupted fish migration to wetlands and over cross hydraulic constructions are for design engineers a scientific challenge to be solved (Kay and Voicu, 2013). Limiting rivers only to minor river bed due to various hydraulic works, agricultural works, and industrial areas and construction of houses near rivers affects the functioning of these lotic ecosystems (Voicu and Voicu, 2015). 
The projected wetland is necessary for fish communities in a zone where the lotic system was channelled in the past, and incorrect activities (river bed and river banks cleaning with heavy machines, destruction of the riverine vegetation, etc.) was performed probably due to the lack of proper management expertise (Fig. 1). This zone is dissimilar from the upstream semi-natural lotic sector where samplings were done (Fig. 2).

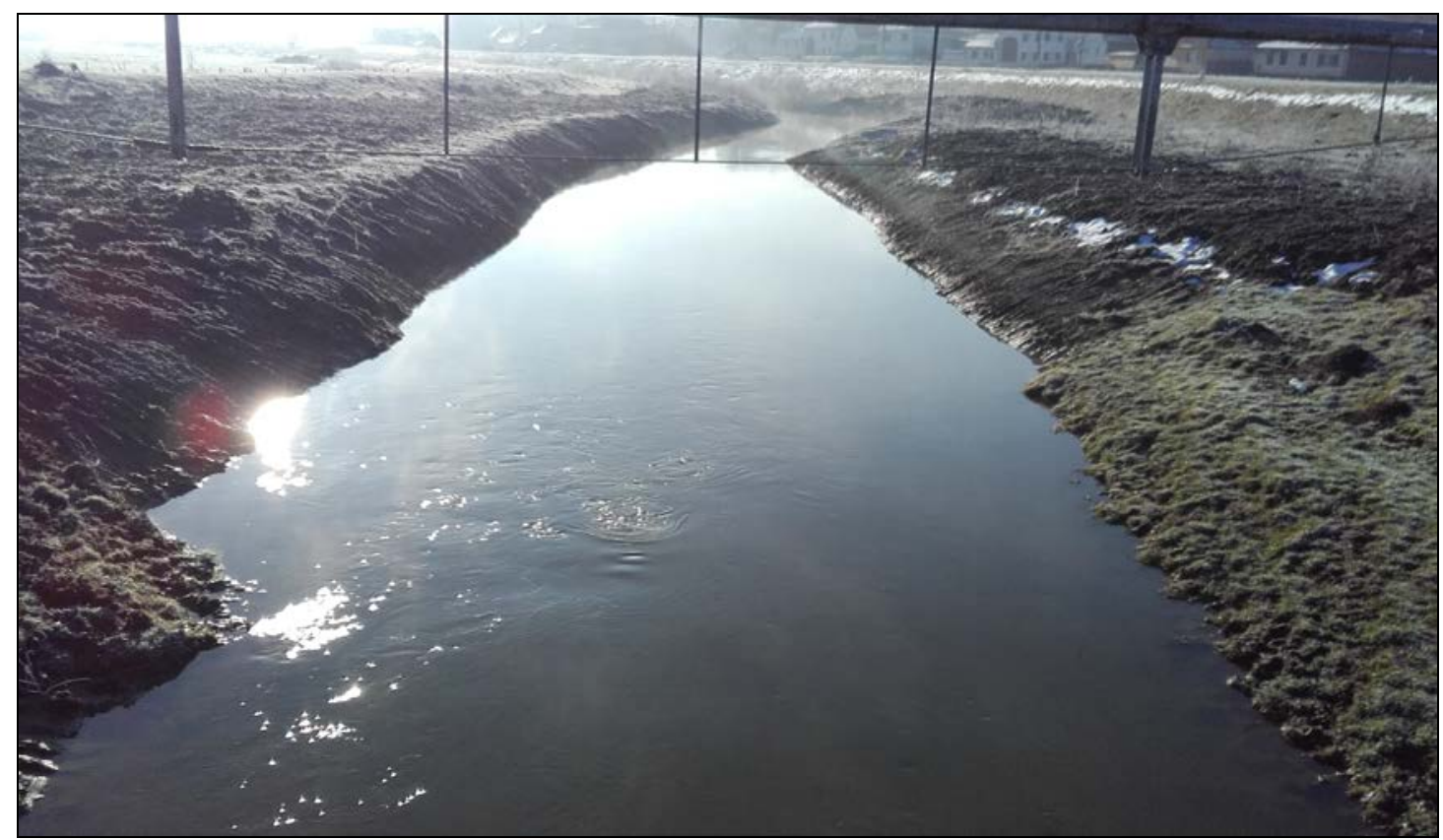

Figure 1: Human impact on the Hârtibaciu River studied sector on banks and riverbed.

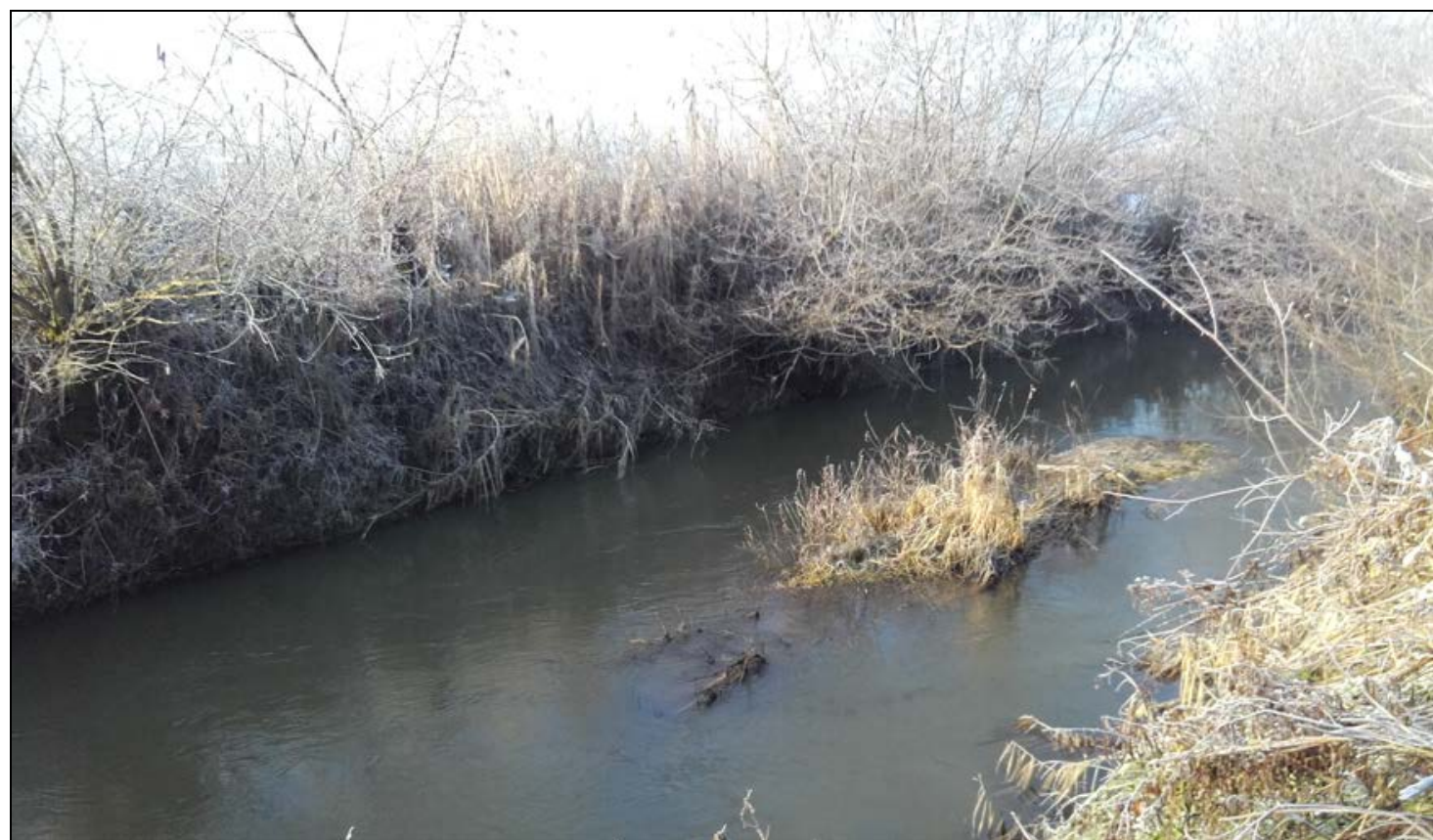

Figure 2: Semi-natural sector of Hârtibaciu River in the studied sector. 


\section{MATERIAL AND METHODS}

To evaluate the necessity for the suggested project the fish association structure was researched in the Alţâna locality (Sibiu County, Romania) proximity of the river Hârtibaciu.

In 2015-2016, a mountain fishing net was used for fishing, in time and effort unit, the captured fish were identified and released back into their habitat at once.

\section{RESULTS AND DISCUSSION}

\section{Local fish association risks and necessity for restoration of habitat}

The fish of river Hârtibaciu contain a rather high number of species of fish: chub, bleak, schneider, European bitterling, gudgeon, Kessler's gudgeon, Mediterranean barbel, Stone loach, Weatherfish, Spined loach, Romanian loach, and Golden spined loach.

At the river Hârtibaciu near the Alțâna locality, a total of five fish species were sampled, namely: chub, schneider, Common nase, European bitterling, and gudgeon. In this research period, Common nase was found for the first time in the Hârtibaciu River.

The formation of the suggested wetland would offer a significant buffer zone for the fish of the area, particularly in the cold and dry periods.

In the researched lotic sector of the river Hârtibaciu, five fish species were sampled: Schneider with a relative abundance of $40 \%$, European bitterling $28 \%$, gudgeon $20 \%$, chub $8 \%$, and Common nase $4 \%$.

The suggested new wetland should be good also for the swan mussel Anodonta cygnea species which is living in the researched area sector. This species offer a symbiotic support for the European bitterling species breeding (Bănărescu and Bănăduc, 2007) and also for their local aquatic self-cleaning mechanism of filter feeding on planktonic algae.

It is relevant to highlight the fact that the European bitterling is a species protected under the Habitats Directive (92/43/EEC). A new wetland area can grow its abundance in the studied area as it offers a characteristic habitat with stagnant and/or semi-stagnant water with smooth type of sediment bottom (Bănărescu and Bănăduc, 2007).

\section{Ecological reconstruction and new wetland area development formation}

In present day the Alțâna Village floodplain tight near the Hârtibaciu River is used for farming and the land is privately owned.

It is therefore suggested the development of some wetland (Fig. 3) downstream of the bridge (Figs. 4a and 4b) whose water supply can be achieved in one of two ways by redirecting water from the Hârtibaciu River gravitationally: a) through a rectangular canal set upstream from the bridge ( $20 \mathrm{~m}$ ) or b) through an existing lateral canal.

The creation of the suggested new wetland area can provide a buffer area for the local fish species, and an accessible passage for their movement. The wetlands related birds, amphibians, molluscs, and vegetation - in particular riparian gallery-like forests and floodplain meadows - can also profit by this wetland, biodiversity will continue to mature, becoming more diverse, balanced and self-sustainable as pioneer species give way to evolving flora. This project can serve as an example for further projects concerning the restoration of connectivity between the river and its floodplain on a larger scale in which it can also be included that the concept of more hydrological and morphological dynamic is characteristic for natural and semi-natural rivers. 


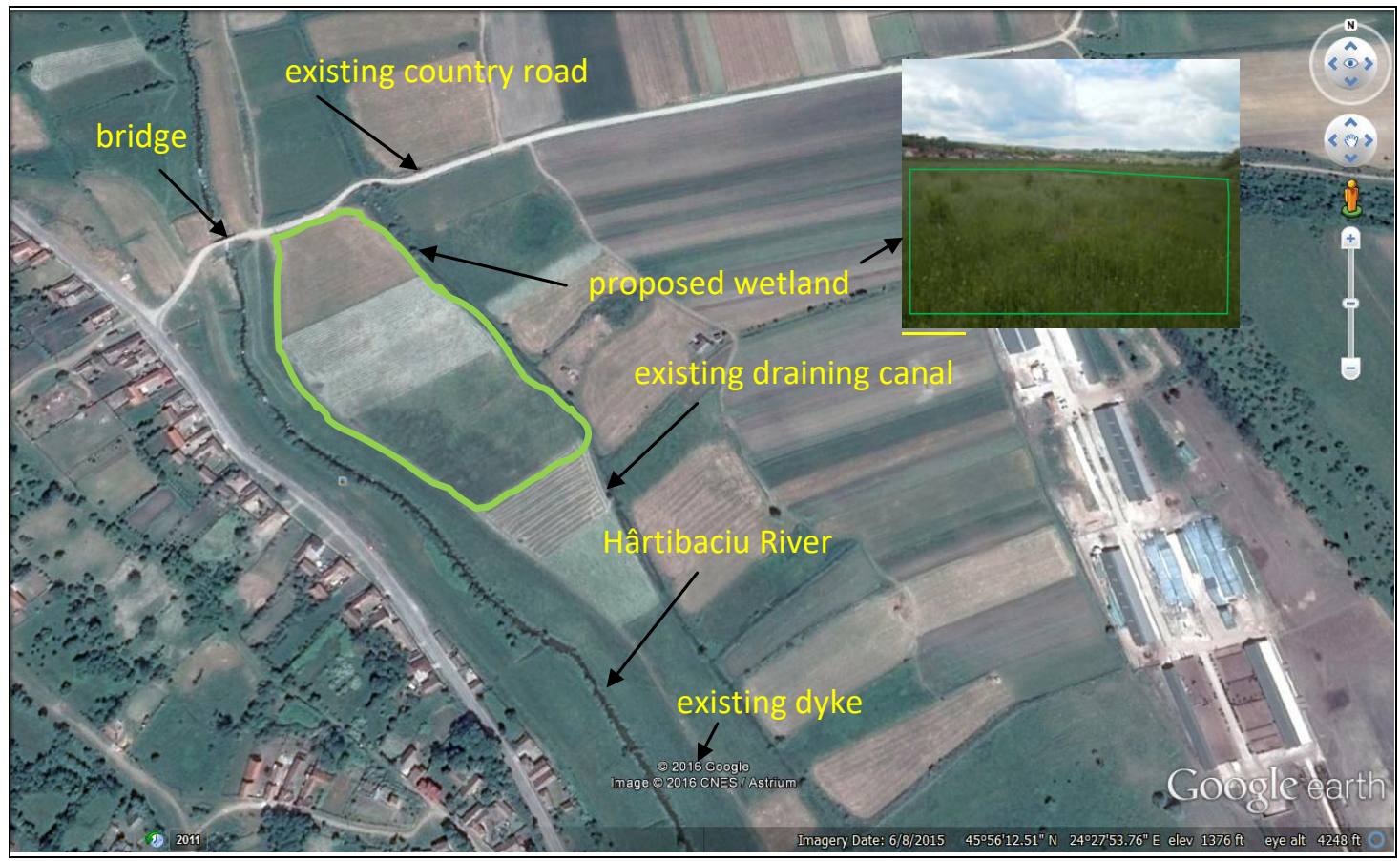

Figura 3: Location of proposed wetland (www.google.com)

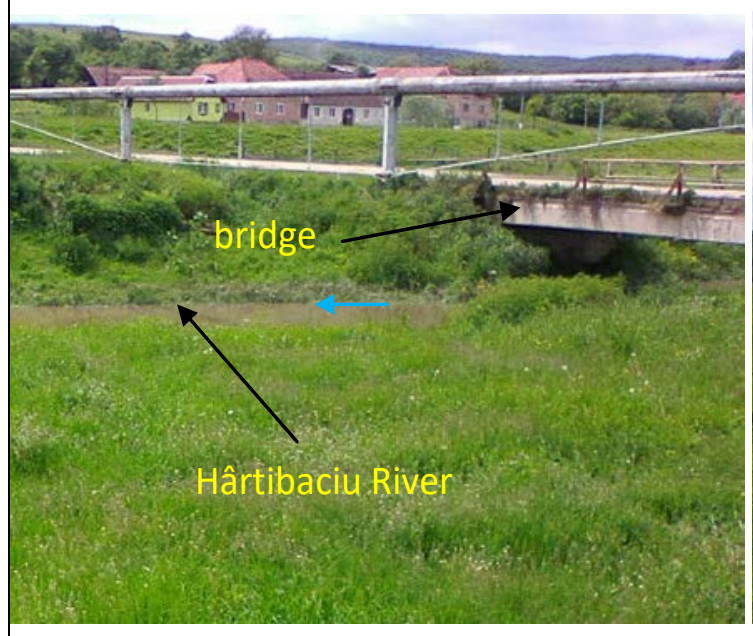

a)

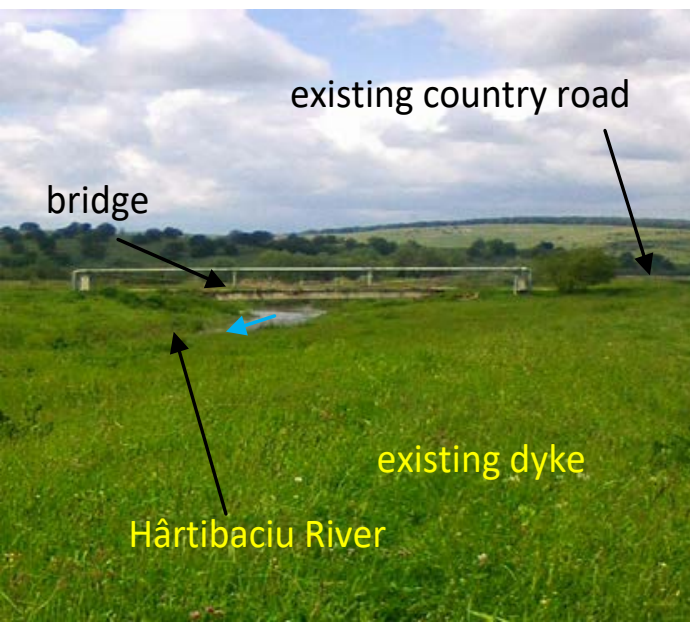

b)

Figure 4: The Hârtibaciu River in Alțâna Village, downstream of the bridge.

\section{Steps in creating the new anthropogenic wetland.}

In a first stage it is suggested to set up the study area as follows.

The entire selected future wetland perimeter is deepened by about $2.5 \mathrm{~m}$ in relation to the current height, while the current banks are linearized and are inclined (Fig. 5a, b). The water level in the new created wetland must be $\sim$ one $\mathrm{m}$, with a number of deeper pools to create a natural sanctuary habitat. 


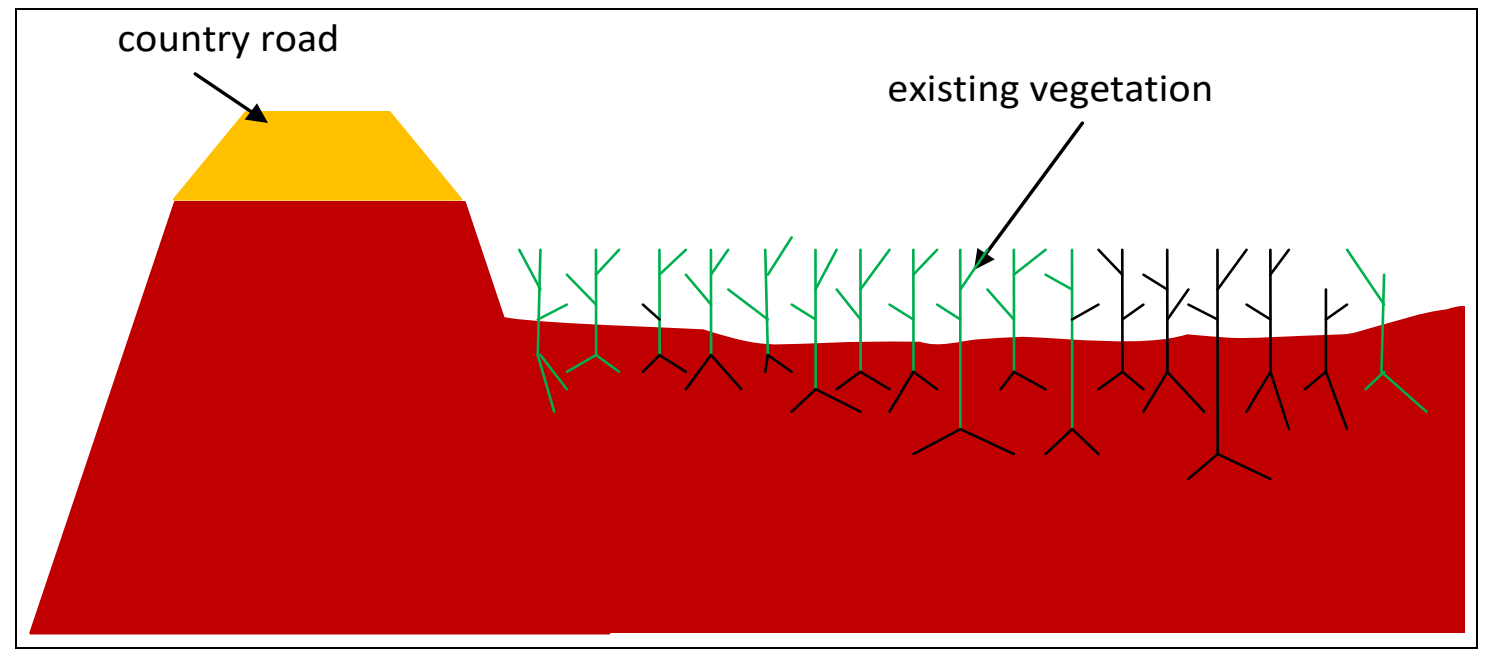

Figure 5a: Current structure of the wetland - indicative scheme.

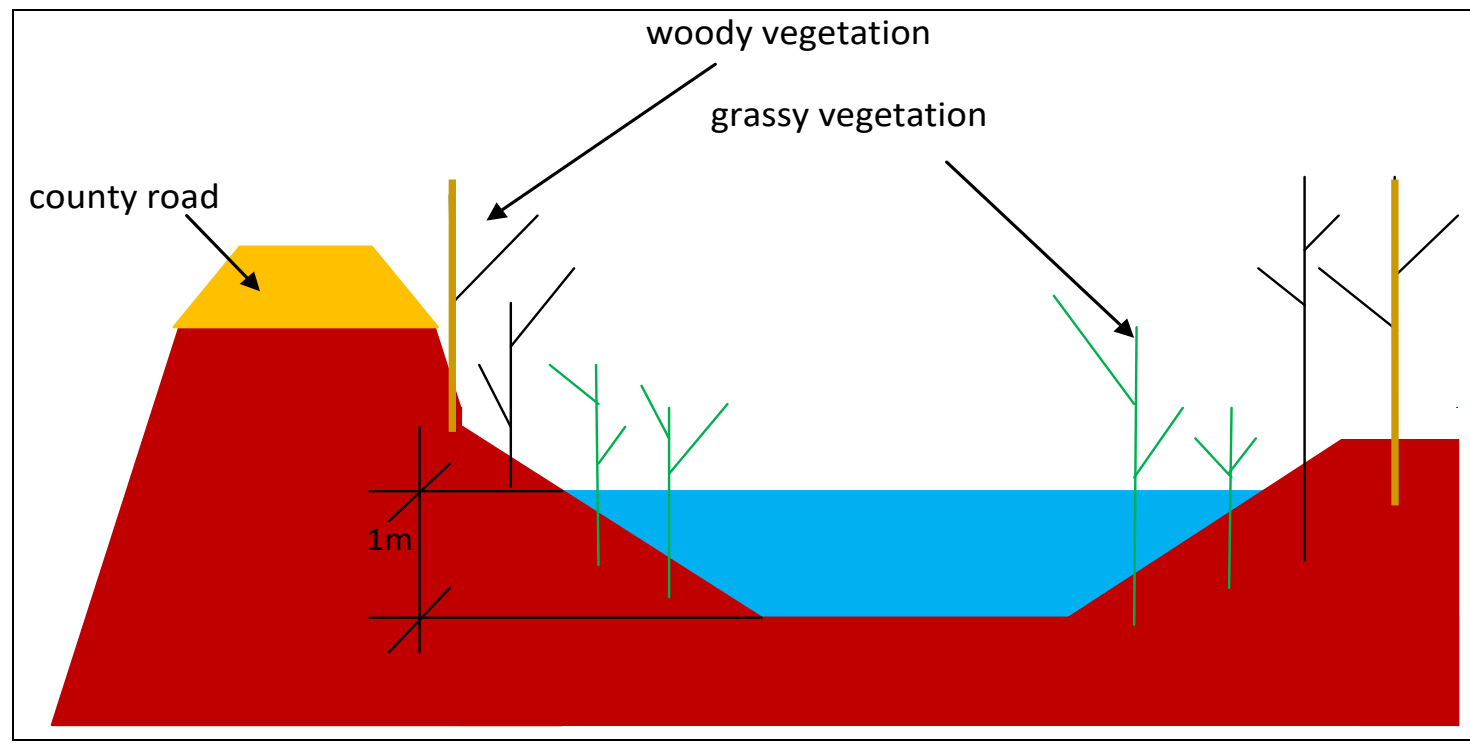

Figure 5b: Restored structure of the wetland - indicative scheme.

On the banks of the basin/wetland, planting of fast-growing woody species (black alder Alnus glutinosa and local characteristic willow species such are Salix alba and Salix fragilis, etc.) is recommended. The roots of these species contribute very quickly for the stability of the bank with minimal technical works. In the same time between the extended roots will develop niches, i.e. hiding places for fish species and as well for site typical macrozoobenthos. On the other hand, it is not recommended to plant either high species, as they may stagger under the wind force thus favouring the landfall, or species of herbaceous plants with tap root as it facilitates the slope stability. The planting of borders of tall herbaceous species and other herbaceous species is not needed because, they will colonise according to our experience in the course of time. But taking into account, that in the surrounding area, there exists riparian fast growing neophytes, an initial planting of site typical species would be necessary, to stop the colonisation by invasive species such are Helianthus decapetalus, Rudbeckia laciniata and Solidago canadensis. 
However, it is recommended to plant species with fascicular roots (ex.: sedge, fescue, etc.) as they prefer moisture soil that can eliminate large amounts of water. On the first created half of bank/inclined plane, it is recommended to plant water dependent species (reed, sedge, fescue, etc.) and on the other half of the inclined plane some woody vegetation (silver poplars, black alders, willow species, etc.) (Fig. 5b). This abundant vegetation growing on the banks of river/wetland will provide habitat for various species of aquatic birds and other aquatic organisms, including fish. This vegetation also has a positive indirect and direct trophic influence for fish (Curtean-Bănăduc et al., 2014). It would be useful to include in the study also the stretch of the Hârtibaciu River around the study area, including a stretch upstream and downstream to be also restored by planting typical riparian vegetation (willow species) as it exists on the Hârtibaciu River more upstream but in representative galleries as exhibited in some downstream sectors (Fig. 4).

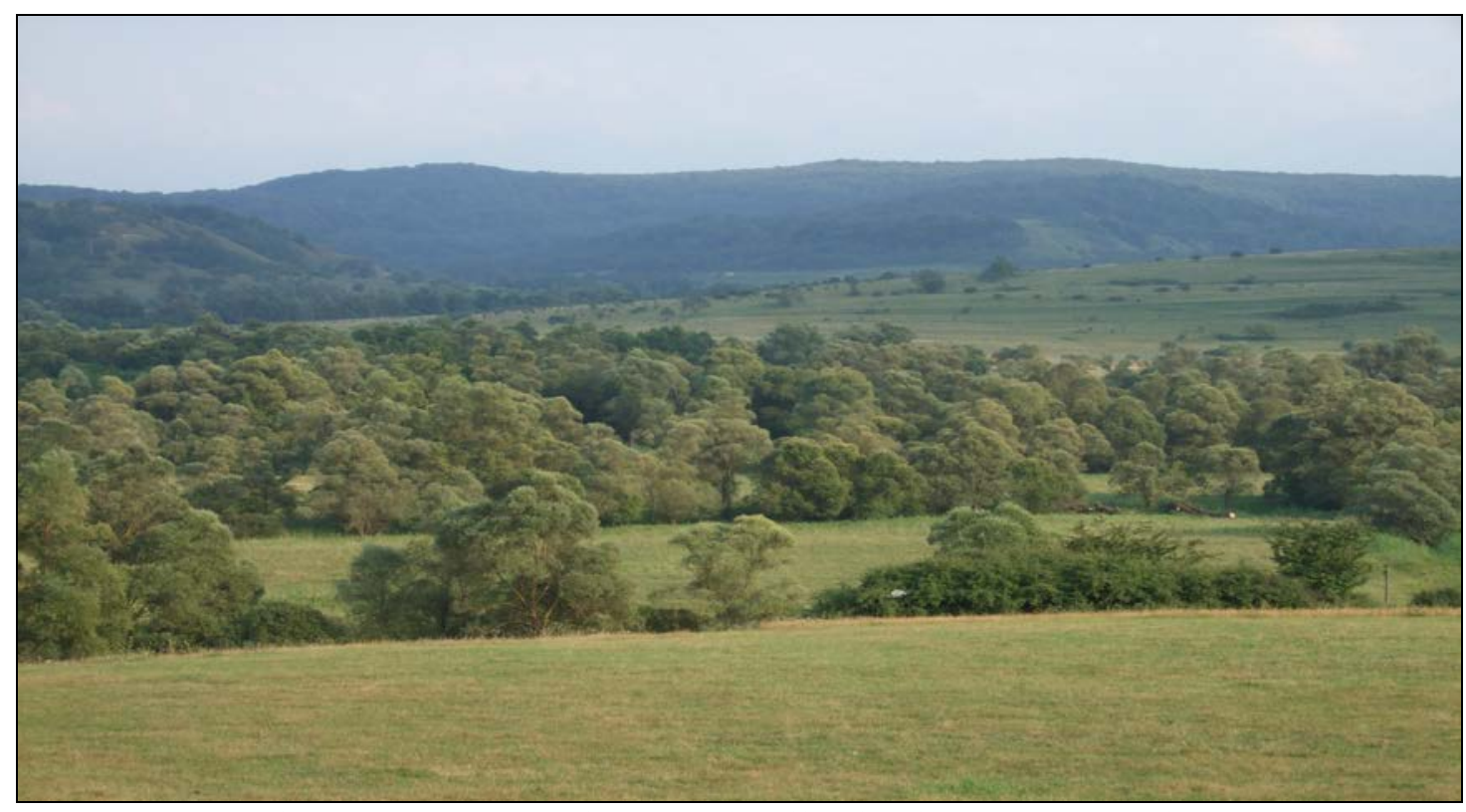

Figure 6: Representative galleries like riverine trees vegetation.

An important aspect when creating a wetland is represented by the continuous water supply system of the wetland. Therefore, within this solution two methods/systems for supplying water to the wetland are proposed, as described below.

\section{First water supply system of the wetland}

It is recommended for water to be gathered from the Hârtibaciu River in a canal situated upstream of the bridge $(\sim 20 \mathrm{~m})$, using some metal sheet piling arranged inside the river. If it would be possible on this canal also it would be good to plant some willows, to increase the ecological value of these technical works and to create on the canal border some small niches for macrozoobenthos and fish species. The upper end of this rectangular canal will be placed near the sheet pile parallel to the left bank of the river (Fig. 7) whilst the lower end of this rectangular canal will be placed near the wetland (Fig. 7). At the upstream end of the canal there will be set a metal grille (Fig. 7) blocking the floating elements and a metal sluice with manual aperture that help maintain this canal and repair the entire water supply system of the wetland. 


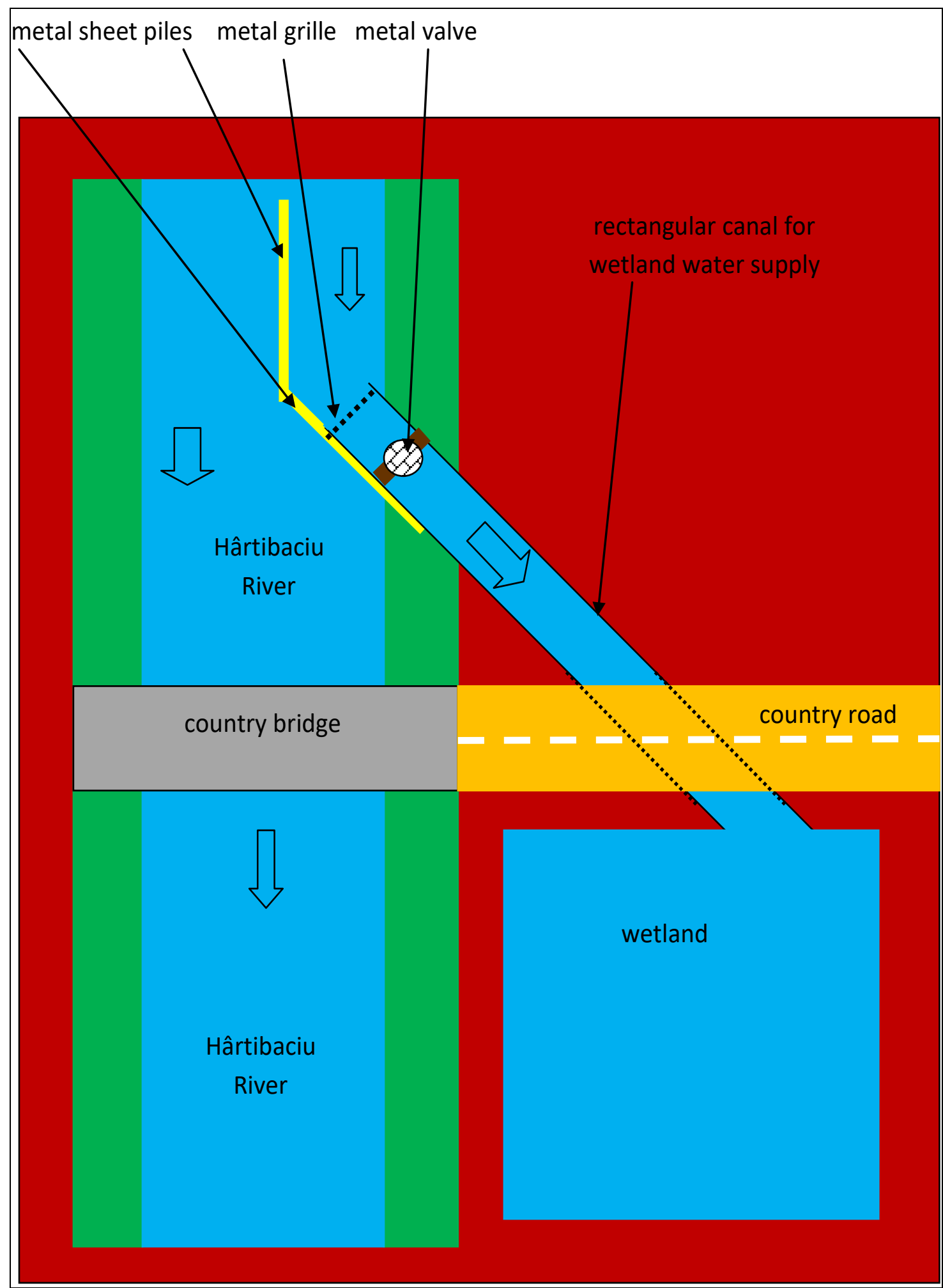

Figure 7: Positioning water supply canal of the wetland - indicative scheme. 
Wetland water supply is realized gravitationally by the means of the rectangular canal. To avoid the erosion of this canal it is recommended to strengthen it by using some wooden bars (treated against moisture) and arranged all over its length (Fig. 8).

The difference between the rectangular channel supplying the wetland and the water surface is one meter. Water discharge into the wetland will be achieved also by a rectangular controlled channel having the same dimensions as the channel for wetland water supply (Fig. 9).

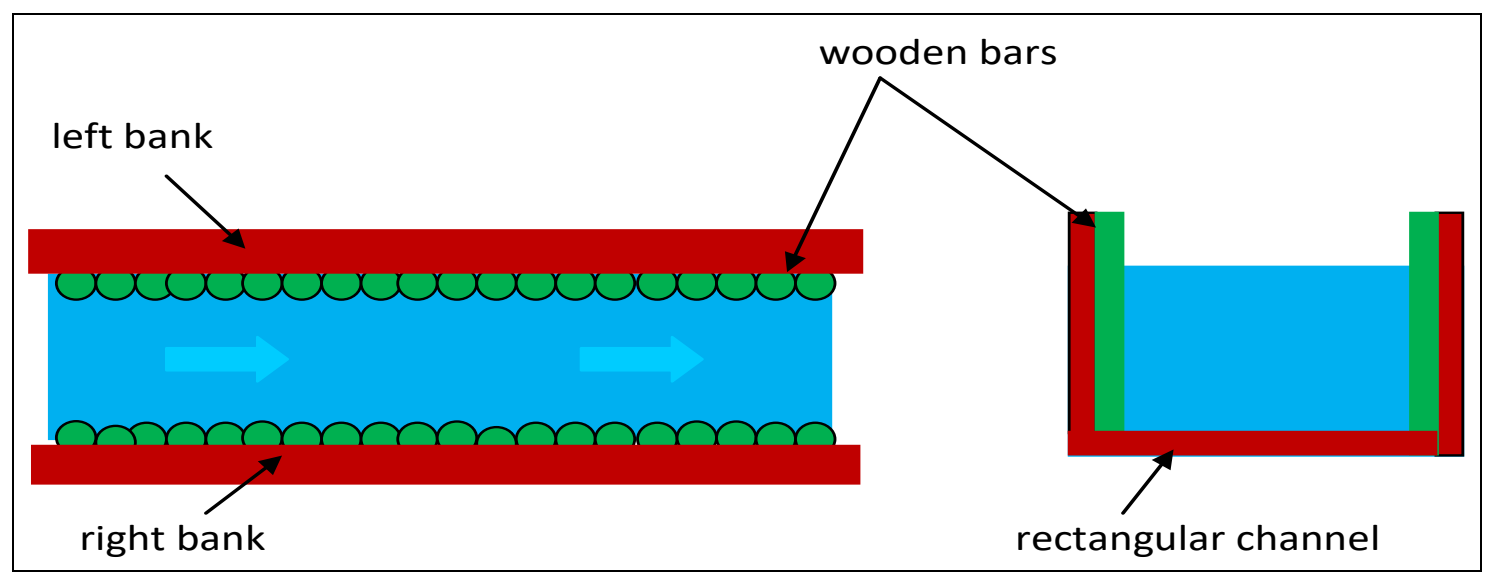

Figure 8: Strengthening the rectangular channel by using some wooden bars - indicative scheme.

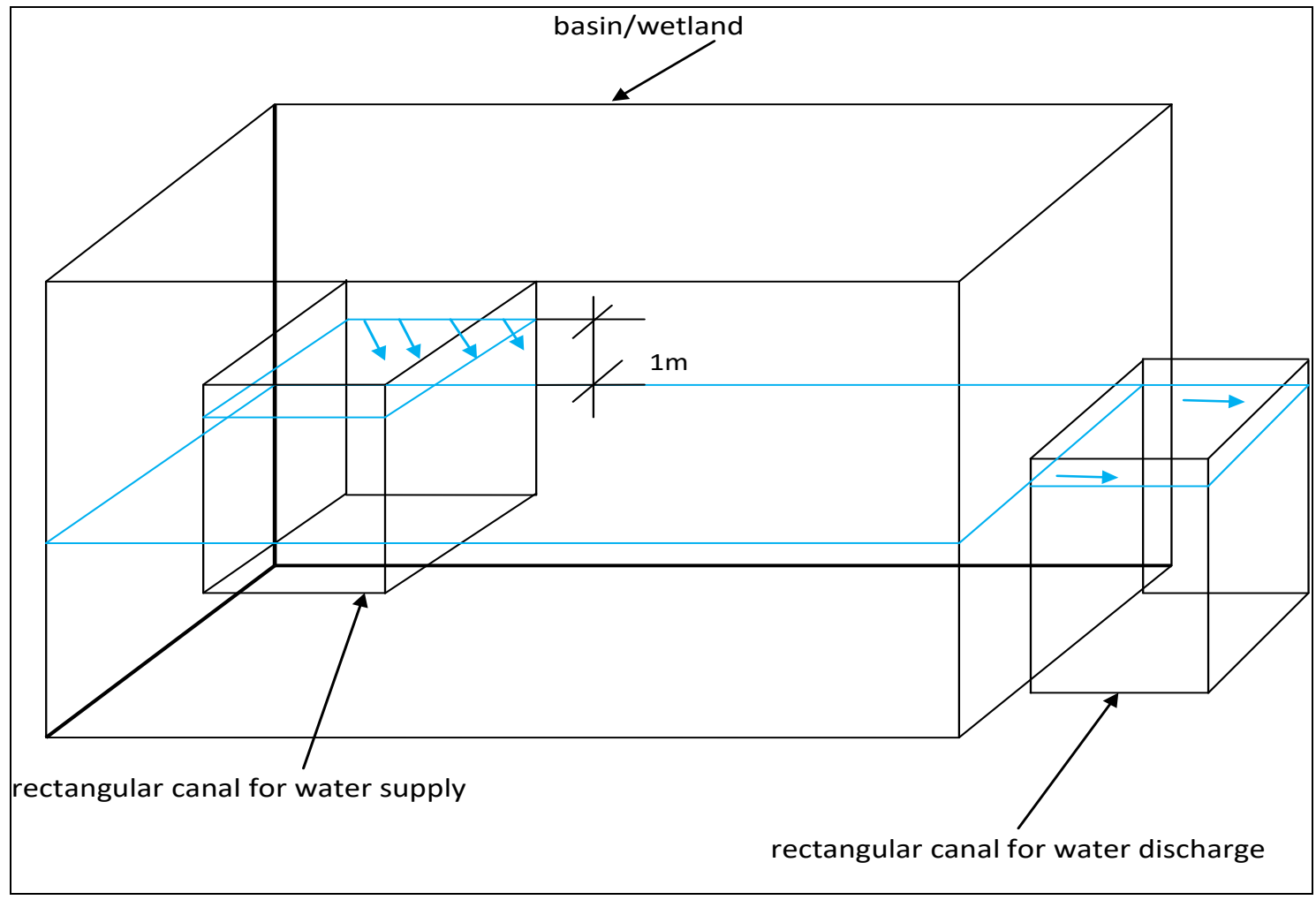

Figure 9: Positioning the canal for water discharge - indicative scheme. 
Because of the water discharge canal, the water level in the created wetland is one $\mathrm{m}$ constantly. Also, the water discharge canal will be arranged like the one for water supply as regarding the banks strengthening. Thus the water discharge into the wetland is achieved gravitationally and directly into the Hârtibaciu River (Fig. 10). No more than $300 \mathrm{~m}$ away from the wetland, the Hârtibaciu River loses $40 \%$ of its maximum rate which actually does not affect the local fish fauna.

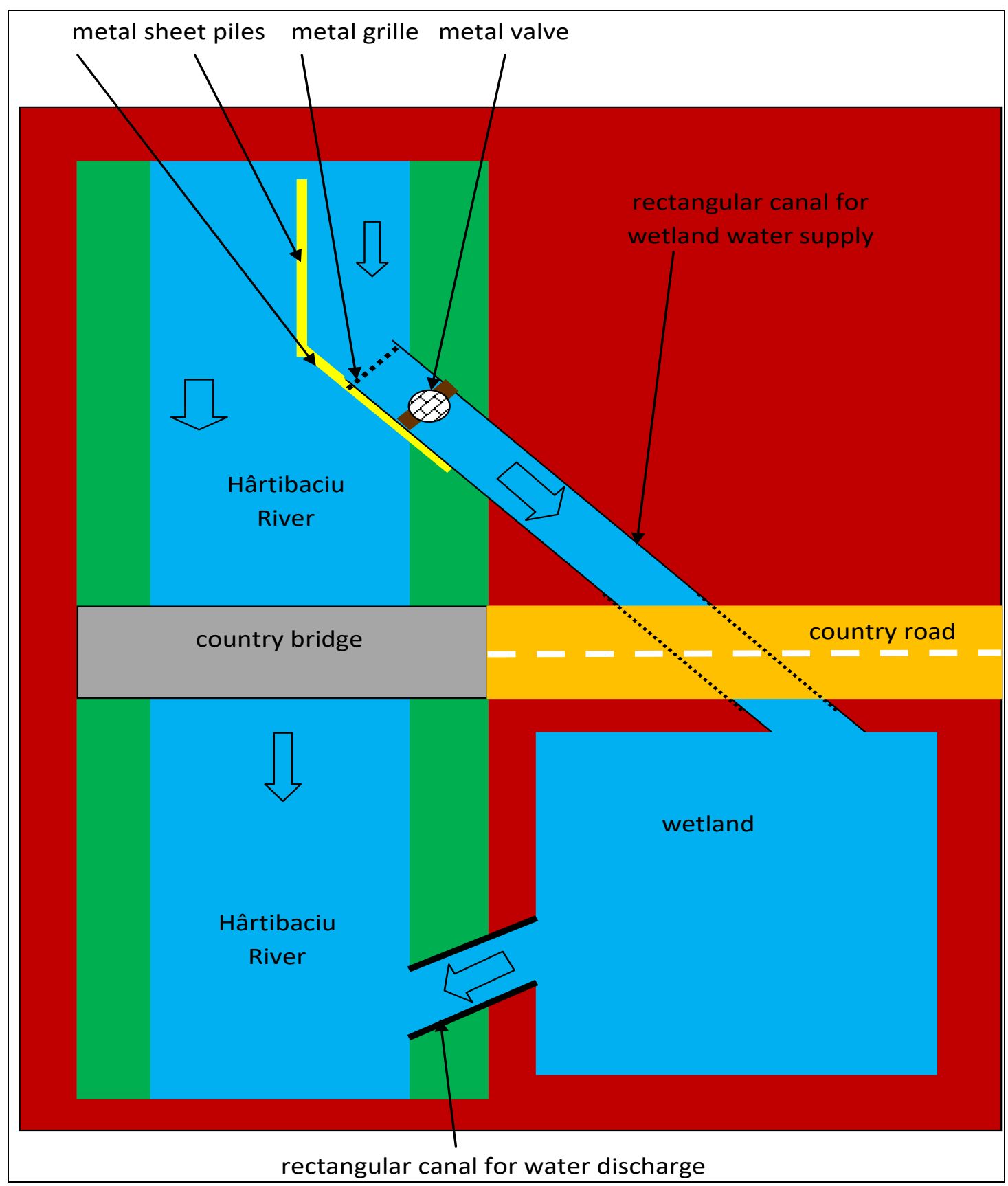

Figure 10: First water supply system of the wetland

- indicative scheme. 


\section{Second water supply system of the wetland}

Another possibility regarding water supply system of the wetland after being arranged (Fig. 5b) is using the existing side canal (Fig. 11).

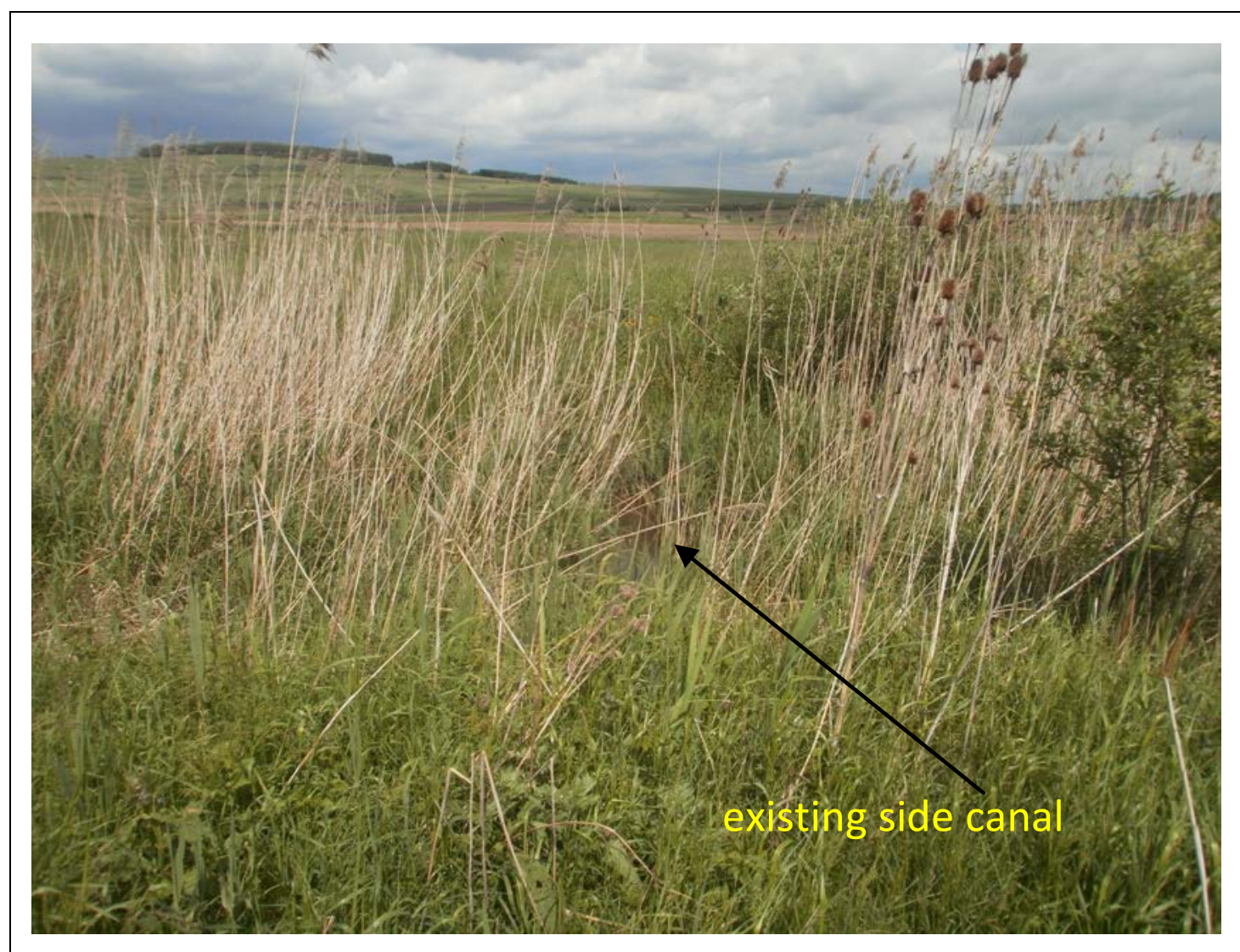

Figure 11: Existing side canal.

Thus, water abstraction from the Hârtibaciu River will be performed by the means of the same type of rectangular canal provided with some metal sheet pile at the upper end (Fig. 6). Unlike the first water supply system described above, the abstracted water will not reach directly the wetland, but the side canal (the existing earth canal). Currently this canal is supplied by rainwater. Its arrangement is proposed in order to capture water from the Hârtibaciu River. Thus, its current shape will change into a trapezoidal one, and then the banks will be linearized (Fig. 12). The arranged canal should be without concrete, stones, etc., permitting by water movements the creation of small niches for some plant species and as well permitting on the banks the planting of site typical willow species. These species offer on their roots valuable microhabitats for different aquatic and semi-aquatic species. 


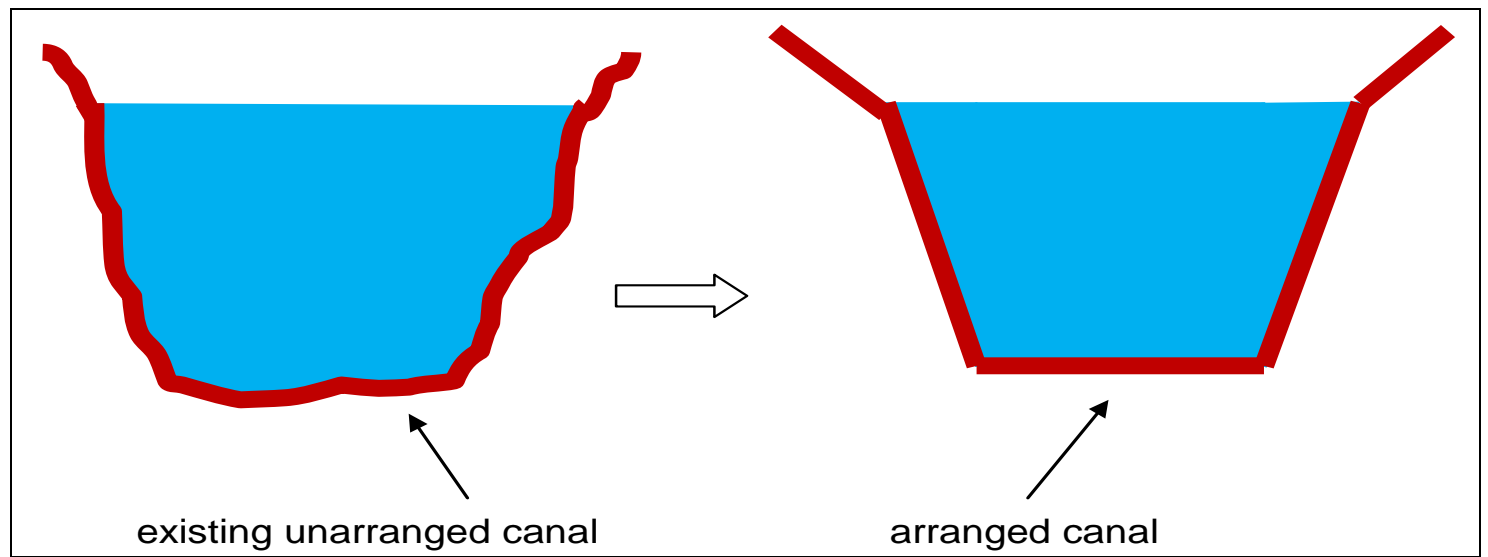

Figure 12: The arrangement of the side canal to supply the wetland.

For water abstraction a rectangular concrete basin upstream is to be built at the upstream end of this existing side canal. The basin will have the following dimensions: three $\mathrm{m}$ height, one m length and $1.5 \mathrm{~m}$ width (Fig. 13).

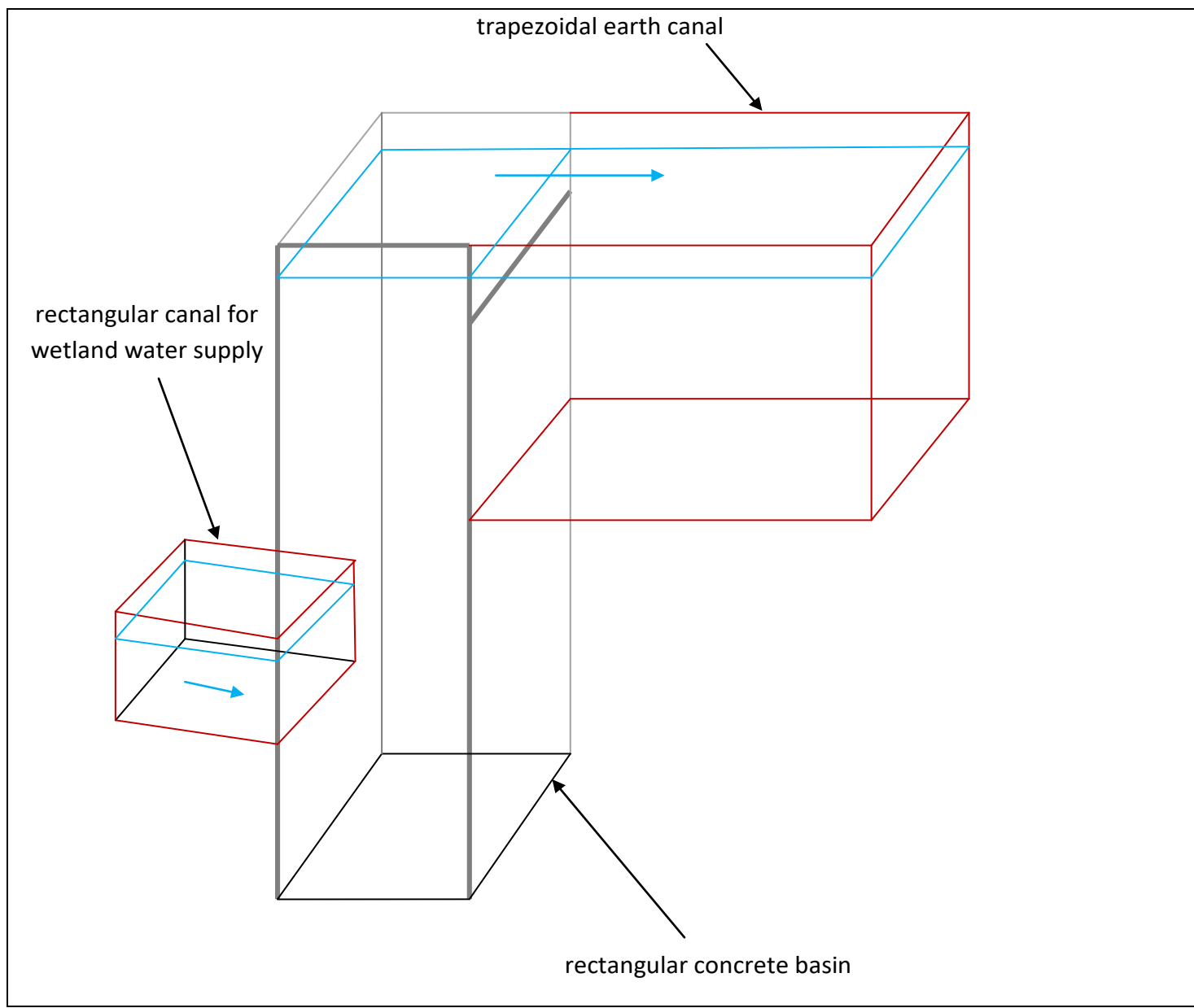

Figure 13: Positioning the rectangular concrete basin. 
Throughout the trapezoidal canal length the wetland water supply will be achieved through four pipelines. At the end of the wetland, inside the trapezoidal canal, a sluice will be fixed (Fig. 13). The difference (waterfall) between the pipelines supplying the wetland gravitationally and the wetland water surface is of one meter. The flow of the four pipelines is the same with the one in the rectangular canal that abstracts water from the Hârtibaciu River.

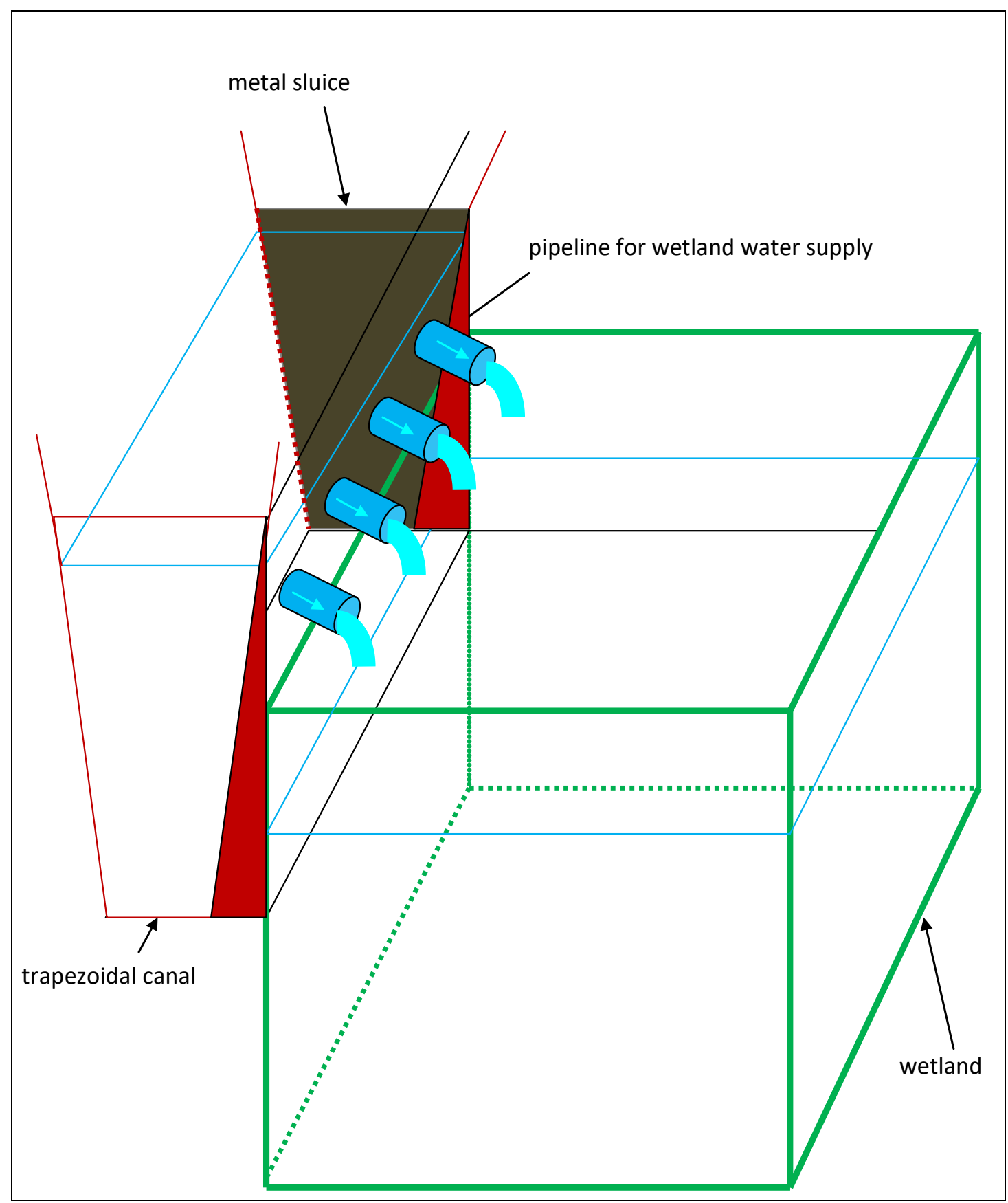

Figure 14: Positioning the water supply pipelines - indicative scheme. 
Discharging water from the wetland (it is proposed that the water level in the wetland to be one m) into the Hârtibaciu River will be achieved through a rectangular canal having the same dimensions as the wetland supply canal (Fig. 15).

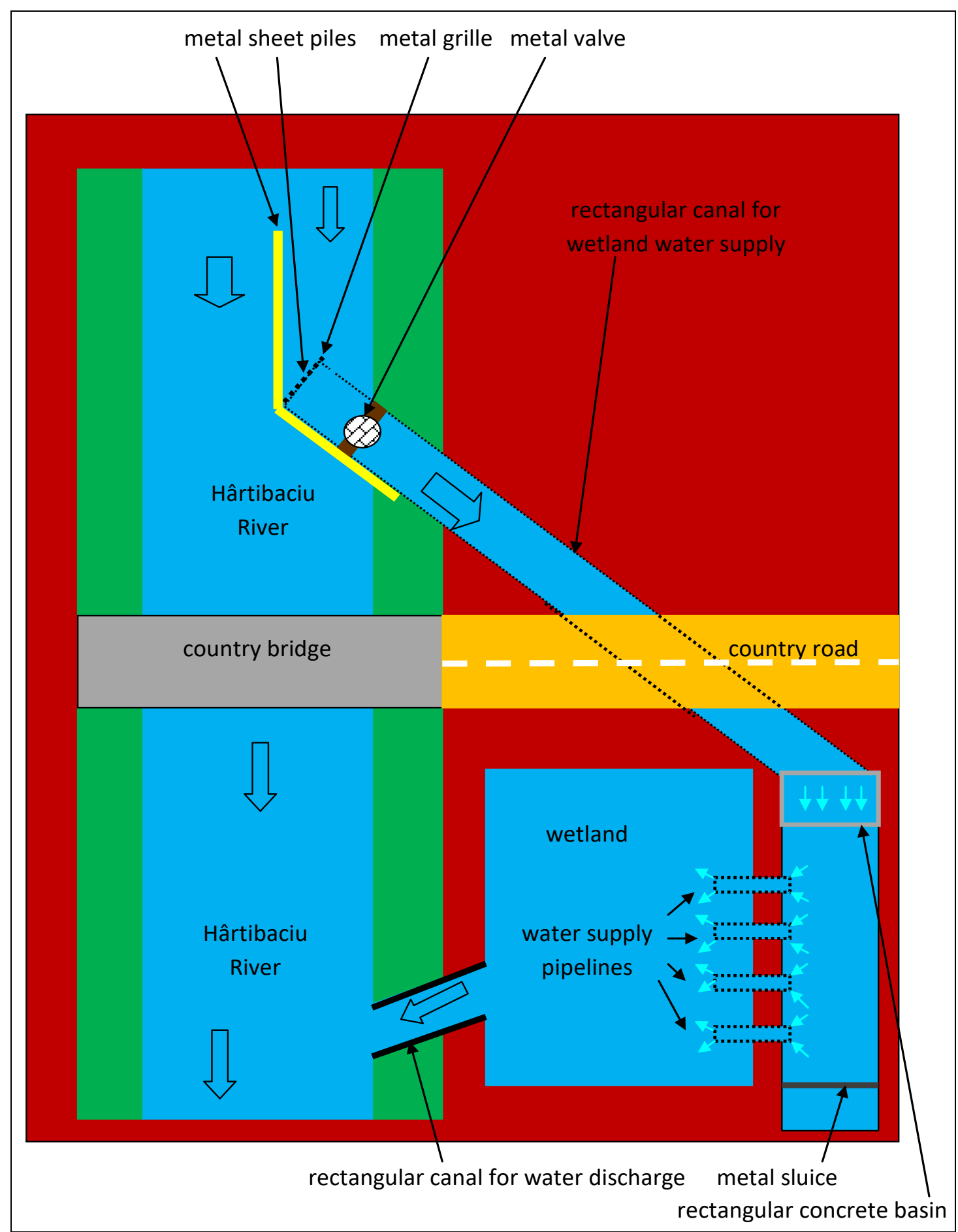

Figure 15: Second water supply system of the wetland - general indicative scheme. 


\section{CONCLUSIONS}

The two important aspects of the solutions proposed in this paper are:

1) The lateral connectivity improvement focusing on the gravitationally achieved water supply for the wetland and that the water discharge coming from the wetland will be directed gravitationally back into the Hârtibaciu River.

2) The local fish fauna will acquire new optimum enhanced habitats and the river system resilience will be increased in the studied lotic sector. 


\section{REFERENCES}

1. Bănăduc D., Rey S., Trichkova T., Lenhardt M. and Curtean-Bănăduc A., 2016 - The Lower Danube River-Danube Delta-North West Black Sea: A pivotal area of major interest for the past, present and future of its fish fauna - A short review, Science of the Total Environment, 545-546, DOI: 10.1016/j.scitotenv.2015.12.05, 137-151.

2. Bănărescu P. M. and Bănăduc D., 2007 - Habitats Directive (92/43/EEC) fish species (Osteichthyes) on the Romanian territory, Acta Ichtiologica Romanica, II, 43-78.

3. Biswas A. K., 2008 - Integrated Water Resources Management: is it working? International Journal of Water Resources Development, 24, 1, 5-22.

4. Curtean-Bănăduc A., Schneider-Binder E. and Bănăduc D., 2014 - The importance of the riverine ligneous vegetation for the Danube Basin lotic ecosystems, in Cianfaglione K. (ed.), L’importanza degli Alberi e del Bosco, Cultura, scienza e coscienza del territorio, Temi Edit., Trento, Italia, ISBN: 978-88-973772-63-9, I-II, 187-210.

5. Gumpinger C. and Scheder C., 2008 - Decline of biodiversity as a result of various human impacts related to river regulation - exemplified by several small river catchments (Austria), Transylvanian Review of Systematical and Ecological Research, 6, 141-148.

6. Hapciuc O.-E., Romanescu G., Minea I., Iosub M., Enea A. and Sandu I., 2016 - Flood susceptibility analysis of the cultural heritage in the Sucevița Catchment (Romania), International Journal of Conservation Science, 7, 2, ISSN: 2067-533X, 501-510.

7. Hoancă D., Todorescu C. and Roşu A., 2014 - Providing longitudinal connection in case of cross sluicing on water bodies in Banat Hydrographic area, Transylvanian Review of Systematical and Ecological Research, 16.2, 151-160, DOI: 10.1515/trser-2015-0024.

8. Ickes B. S., Vallazza J., Kalas J. and Knights B., 2005 - River floodplain connectivity and lateral fish passage: A literature review, U.S. Geological Survey, Upper Midwest Environmental Sciences Center, La Crosse, Wisconsin, June 2005, 25.

9. Jeeva V., Kumar S., Verma D. and Rumana H. S., 2011 - River fragmentation and connectivity problems in Gange River of upper Himalayas: the effect on the fish communities (India), Transylvanian Review of Systematical and Ecological Research, 12, The Wetlands Diversity, 75-90.

10. Kay E. L. and Voicu R., 2013 - Developing an ecological and migration system for ichthyofauna on the Crişul Repede River near the City Hall of Oradea, Management of Sustainable Developmen, Sibiu, Romania, 5, 2, 27-33.

11. Voicu R. and Voicu L., 2015 - The proposal of potential solutions in order to restore the Bârzeşti-Brăhăşoaia wetland within the Bârlad hydrographic basin, Lakes, reservoirs and ponds, 9, 2, 77-95.

12. Voicu R. and Dominguez L., 2016 - Facilitation fish migration above the discharge sill located on the ialomiţa river near cave Ialomicioara, Annals of Valahia University of Târgovişte, Geographical Series, 16, 2, 44-58.

13. van Wilgen B. W., Le Maitre D. C. and Cowling R. M., 1998 - Ecosystem services, efficiency, sustainability and equity: working for water programme, Trends in Ecology and Evolution, 13, 9, 378. 